\title{
Strategies for Achieving Quality Assurance in Science Education in Akwa Ibom State of Nigeria
}

\author{
Akinbobola, A. O. \& G. A. Ikitde
}

\begin{abstract}
This paper examined the strategies for achieving quality assurance in science education in Akwa Ibom State of Nigeria. The design adopted for this study was survey design. A total of 300 science teachers randomly selected from the technical colleges and secondary schools took part in the study. Strategies for Achieving Quality Assurance in Science Education Questionnaire (SAQASEQ) was the instrument used in gathering data for the study and the reliability coefficient was 0.79 using Cronbach alpha. The results showed an insignificant difference existing in the salaries and allowances given to science teachers and other teachers. The results also showed that there were more qualified science teachers in secondary schools than technical colleges. The results equally indicated that science equipment currently available in technical colleges and secondary schools were inadequate and students in technical colleges utilize science equipment more than the students in secondary schools. Conclusion from the findings led to the recommendation of various strategies for achieving and maintaining quality assurance in science education in Akwa Ibom State of Nigeria.
\end{abstract}

Keywords: $\quad$ Quality Assurance, Science Education, Strategies

\section{Introduction}

The concept of quality in academics is the concept of quality of educational input and output in its entirety. Quality is considered as baseline standard in education, which can be measured on a scale of preference. Standards imply accepted principles, rules, guidelines or 
levels established by group of people, organizations or societies. Bisong (2000) is of the opinion that the educational enterprise has to do with establishing and maintaining standards, which form the basis of evaluation. Quality therefore is an expression of standard or it is the means by which a certain set standard in education can be achieved. This can be assessed in respect of many factors that exist within the academic system. It addresses the issue of accountability in educational practice in terms of the use put to materials and personnel. The material and personnel resources when broken down cover many areas of educational practice. Walklin (1992) defined quality assurance as the avoidance of non-performance by pre-empting failure through proper planning, execution, monitoring and evaluation. It is a way of managing an organization so that every job, every process, is implemented right first time and always. Ukeje, Akabogu \& Ndu (1992) explain that quality assurance in a school setting is made possible through proper planning by the management which involve all the staff in the functions of planning, execution, monitoring and evaluation using set standards and objectives.

The SEAMEO VOCTECH: Southeast Asian Minister of Education Organization Regional Centre for Vocational and Technical Education and Training (VTET) in its efforts to provide quality assurance in its product and services, has instituted the six (6) strategic goals reflected in its 3rd five year development plan (2004/5 - 2008/9), as follows:

- Developed and implemented relevant, innovative and quality capability building programmes geared towards sustainable development

- Institutionalized research and development initiatives

- Enhanced human resource development

- Instilled a dynamic organizational culture

- Intensified networks and partnership 
- Optimized resources and operation of information services

The goals are being operationalized through the application of quality management to facilitate continuous upgrading/improving of the different programme areas to strengthen VTET institutions in the SEAMEO VOCTECH member countries, for example, training, research and development, ICT and information services thus achieving quality assurance in the process. It is recognized in the field of VTET that quality assurance can be measured through the quality inputs, process and output of the learning institutions in terms of producing skilled and competent work force (Mosbi, 2005).

Quality assurance can be improved upon in science education by making provision for learning facilities and equipment. Onyemachi and Ekong (1999) described instructional materials as all the practical and skill development resources that facilitate the processes of teaching, learning and evaluation of vocational technical skills. It includes all electronic systems, tools, equipment and other resource materials that could be utilized for directing and controlling vocational technical operations thus reinforcing the teaching and learning of specific skills. It is no gainsaying that most of our institutions lack basic infrastructure and equipment to carry out effective teaching and learning which will guarantee quality assurance.

Quality assurance can also be improved upon by adequate staffing which will definitely provide the framework within which teachers' workload can be reduced to enhance efficiency and quality. If teacherstudent ratio does not improve, the consequence is a substantial decline in teachers' relative performance. Nwoke (1990) agreed that serious shortfalls have always existed in the number of professionally 
qualified science and technical teachers needed in the nation's schools and colleges.

Teaching is a profession and no better education system can rise above the quality of its teachers. Bisong (2000) stated that the quality and standard of teacher education and teaching have declined. He reemphasized that any person who intends to or is teaching must obtain a qualification in education (teaching) before practising at any educational level. Uche (1980) on in-service training programmes for teachers revealed that the programmes improved the teaching skills of the recipients as well as enhanced their job performance. In support, Ibadin (1991) revealed that the various, forms of in-service education with particular reference to regular, weekend and sandwich programmes improved the performance of the recipients, improved their academic and or professional attainment as well as prepared them for roles. Quality assurance can be improved upon by regular attendance of science teachers at workshops, conferences and seminars.

There is need to improve teachers remuneration beyond what it is presently, as high wages may tend to produce commitment and efficiency. Bloomer (1980) observed that if quality and professionalism is to be encouraged it must be rewarded. According to him, salary has a potent influence upon the attitude of teachers as on other workers.

\section{The Problem}

The quality of science education is affected by policy and contextual factors within the environment, the availability of inputs, the processes and the consumers of the products of science education. The future of any nation in the modern world depends to a great extent, on the educational system. Low quality teachers and low quality facilities 
necessarily imply low quality products and low quality performance in the society by such products. Ali (2000) reviewed the quality of teachers in the seven - year period 1993 - 2000 and found that it had been falling. He also noted lack of adequate practical experience in schools due to lack of adequate workshops/laboratories, equipment and instructional materials. What are the things or issues that can make for quality assurance in science education in Nigeria?

\section{Purpose of the Study}

The purpose of this study is to find out the strategies for achieving quality assurance in science education in Akwa Ibom State of Nigeria. The study is designed to achieve the following specific objectives:

1. To ascertain whether special allowance is given to science teachers in Akwa Ibom State of Nigeria.

2. To assess whether there is any difference in the qualifications of science teachers in technical colleges and secondary schools for quality assurance in Akwa Ibom State of Nigeria.

3. To compare the availability of the science equipment in technical colleges and secondary schools for quality assurance in Akwa Ibom States of Nigeria.

4. To compare the use of available science equipment in technical colleges and secondary schools for quality assurance in Akwa Ibom State of Nigeria.

\section{Hypotheses}

The following hypotheses were formulated and tested to guide the investigation at .05 level of significance:

1. There is no significant difference in the salaries and allowances given to science teachers and other teachers for quality assurance in Akwa Ibom State of Nigeria. 
2. There is no significant difference in the qualifications of science teachers in technical colleges and secondary schools for quality assurance in Akwa Ibom State of Nigeria.

3. There is no significant difference in the number of science equipment available for use in technical colleges and secondary schools for quality assurance in Akwa Ibom State of Nigeria.

4. There is no significant difference in the use of science equipment in technical colleges and secondary schools for quality assurance in Akwa Ibom State of Nigeria.

\section{Research Method}

The design adopted in this study was survey design .The population of the study comprised 155 science teachers in all the technical colleges and 768 science teachers in all the 241 public secondary schools in Akwa Ibom State. The sample consisted of 300 science teachers (150 from technical colleges and 150 from secondary schools) randomly selected from the technical colleges and secondary schools in the population. A random sampling technique was used to select science teachers from the population.

The instrument used in gathering data for the study was a researcher designed questionnaire tagged Strategies for Achieving Quality Assurance in Science Education Questionnaire (SAQASEQ), which was constructed by the researchers. Section A of the instrument contained demographic data such as sex, name of school, qualification, area of specialization, age and subject taught. Section B is a structured 4-point rating scale containing information about the remuneration of teachers, staff development, and uses of equipment. Section C contained the number of available equipment in each unit of science education. Two science teachers and two science experts validated the instrument. A trial testing was carried out using 40 
science teachers not selected for the main study. The data obtained was subjected to Cronbach alpha and the result showed a reliability coefficient of .79. The instrument (SAQASEQ) was administered to all the subjects selected for the study and they were assured of the confidentiality of their responses. The data collected were analyzed using independent t-test and chi-square. All the hypotheses were tested at .05 level of significance.

\section{Results}

\section{Hypothesis One}

There is no significant difference in the salaries and allowances given to science teachers and other teachers for quality assurance in Akwa Ibom State of Nigeria.

As shown in Table 1, the calculated t-value of 1.74 was less than the critical t-value of 1.96. Thus the null hypothesis stating a non significant difference in the salaries and allowances given to science teachers and other teachers for quality assurance in Akwa Ibom State of Nigeria was retained.

\section{Hypothesis Two}

There is no significant difference in the qualifications of science teachers in technical colleges and secondary schools for quality assurance in Akwa Ibom State of Nigeria

The analysis is as shown in Table 2.

As shown in Table 2, the calculated $\mathrm{X}^{2}$-value of 16.1 is greater than the critical $X^{2}$-value of 5.99. Thus, the null hypothesis which stated that there is no significant difference in the qualification of science teachers in technical colleges and secondary schools for quality assurance in Akwa Ibom State of Nigeria was rejected. 


\section{Hypothesis Three}

There is no significant difference in the number of science equipment available in technical colleges and secondary schools for quality assurance in Akwa Ibom State of Nigeria.

As shown in Table 3, the calculated $\mathrm{X}^{2}$-value of .90 is less than the critical $\mathrm{X}^{2}$ value of 3.84 . Thus, the null hypothesis which stated that there is no significant difference between the number of science equipment available in technical colleges and secondary schools for quality assurance in Akwa Ibom State of Nigeria was retained.

\section{Hypothesis Four}

There is no significant difference in the uses of science equipment in technical colleges and secondary schools for quality assurance in Akwa Ibom State of Nigeria.

As shown in Table 4, the calculated $\mathrm{X}^{2}$ - value of 12.58 is greater than the critical $\mathrm{X}^{2}$-value of 5.99. Thus, the null hypothesis which stated that there is no significant difference in the uses of science equipment in technical colleges and secondary schools for quality assurance in Akwa Ibom State of Nigeria was rejected.

\section{Discussion}

The results of hypothesis one indicated that a non-significant difference in the salary and allowances given to science teachers and other teachers for quality assurance in Akwa Ibom State of Nigeria. The findings revealed that science teachers are not well paid. The values of science education for technological growth and development should attract greater earnings. This result is in agreement with Bloomer (1980) that if quality and professionalism is to be encouraged, it must be rewarded. 
The results of hypothesis two showed that a significant difference was found to exist in the qualifications of science teachers in technical colleges and secondary schools for quality assurance in Akwa Ibom State of Nigeria. The result in Table 1 indicated that we have more qualified science teachers in the secondary schools than technical colleges in Akwa Ibom State of Nigeria. This is in line with the findings of Nwoke (1990) that serious shortfalls have always existed in the number of professionally qualified science and technical teachers needed in the nation's schools and colleges.

The results of hypothesis three indicated that a non-significant difference exists between the number of science equipment available for use in technical colleges and secondary schools for quality assurance in Akwa Ibom State of Nigeria. The analysis in Table 3 showed that some of the science equipment needed are not available and therefore inadequate in making the State technologically developed. The result was consistent with the findings of Onyemachi and Ekong (1999) that most of our institutions lack basic infrastructure and equipment to carry out effective teaching and learning and skills development.

The results of hypothesis four showed that a significant difference was found to exist between uses of science equipment in technical colleges and secondary schools for quality assurance in Akwa Ibom State of Nigeria. The analysis in Table 4 indicated that science equipment in technical colleges are more utilized than In secondary schools. This might be due to the fact that the curriculum of science education in technical colleges is more structured towards practical that equip individuals with job skills which ensure a self-reliant life and consequently reduce unemployment in the state and help the country attain higher national productivity. This is in line with the findings of 
Osuala (1987) that utilization of equipment is needed by students to enable them become skilled in trades and various technical occupations.

\section{Conclusion}

Based on the above findings, the following conclusions were made:

- No special allowances are given to science teachers in technical colleges and secondary schools in Akwa Ibom State of Nigeria. Hence, morale will be extremely low and teachers' productivity is bound to wane.

- There are more qualified science teachers in secondary schools than technical colleges in Akwa Ibom State of Nigeria.

- Science equipment currently available in technical colleges and secondary schools in Akwa Ibom State of Nigeria are in short supply and therefore incapable of making the state technologically developed.

- Students in technical colleges utilize science equipment more than the students in secondary schools in Akwa Ibom State of Nigeria.

\section{Strategies for Achieving and Maintaining Quality Assurance in Science Education}

The findings of the study already discussed and the conclusion from the findings formed the basis of all recommendations put forward in this study for strategies for achieving and maintaining quality assurance in science education in Akwa Ibom State of Nigeria. These are articulated as follows:

1. Seminars, workshops and conferences should be organized regularly for science teachers to acquaint them with the use of the equipment. 
2. An implementation committee on science education should be set up and this committee should always be made up of people who are science experts.

3. A built-in evaluation instrument should be constructed as an appendage of implementation committee document for the purpose of periodical evaluation of both the implementation processes and the success or failure of science education programme.

4. There should be regular inspection of schools from the science section of the Ministries of Education (Federal and State) in Nigeria. This inspection should focus on school accountability process, maintenance of equipment, improving performance and quality of teaching and developing an annual report covering school performance, students' achievement and financial performance.

5. More science teachers should be trained and employed in Nigeria to be able to cope with the increase in the population of students.

6. Efforts should be geared towards the provision of science equipment necessary for enhancing science education programme in Akwa Ibom State of Nigeria by the State government, philanthropist, communities, private sectors and organizations.

7. Special allowances should be paid to science teachers to boost their morale for high productivity.

8. There should be a monitoring team from the State and Federal Ministries of Education to check on-going science education programmes for flaws or breakdowns, provision of information to regulate activities and undertake corrective actions.

9. Science teachers should be encouraged to attend in-service trainings such as sandwich and part-time training through government sponsorship in Nigeria. 


\section{References}

Ali, A. (2000). "Teacher Production, Utilization and Turnover Pattern in Nigeria.” In K. Isyaku, C. M. Anikweze, A. A. Maiyanga, \& G. M. Olukun (Eds.), Teacher Production, Utilization and Turnover Patterns in Nigeria. Kaduna: National Commission for Colleges of Education.

Bisong, J. O. (2000) "Quality and Competence in Teacher Education." In A. M. Wochocha (Ed.), Quality in Nigerian Educations Agenda for Action. Port Harcourt: Osia International Publishers Ltd.

Bloomer, K. (1980). Teacher as Professional and Trade Unionist: Professional Development of Teachers. World Yearbook of Education.

Ibadin, V. O. (1991). An Analysis of the Effects of In-Service Training Programmes on the Teaching Performance of Secondary School Teachers in Bendel State Nigeria. Unpublished Ph.D Thesis, University of Benin, Benin City.

Mosbi, N. H. (2005). Quality Assurance in SEAMEO Vocational and Technical Education and Training. A Paper Presented At the InterGovernmental Workshop on Regional Accreditation Modelling and Accrediting the Accreditors At Colombo Plan Staff College, Philippines. 25 - 26 August.

Nwoke, N. (1990). Teacher Education in Nigeria. Calabar: Wusen Press Ltd. Onyemachi, G. A. \& Ekong, A. O. (1999). Curriculum Development and Management in Vocational Technical Education. Onitsha: Cape Publishers Int. Ltd.

Osuala, E, C. (1987). A Handbook of Vocational - Technical Education for Nigeria. Uruowulu - Obosi: Pacific Publishers.

Uche, U. W. (1980). In-Service Education Programme for Teachers' Trainers. West African Journal of Education, 27 (1), 20 - 24.

Ukeje, B. 0., Akabogu, G. \& Ndu, A. N. (1992). Educational Administration. Enugu: Fourth Dimension Publishing Company Ltd.

Walkin, L. (1992). Putting Quality into Practice. Cheltenham: Stanley Thomas Publishers Ltd. 
Table 1: t-test comparison of remuneration given to science teachers and other teachers

\begin{tabular}{lccccccc}
\hline Remuneration & $\mathbf{N}$ & $\mathbf{X}$ & SD & DF & t-Cal. & t- Critical & $\begin{array}{c}\text { Decision } \\
\text { at } \mathbf{P}<.05\end{array}$ \\
\hline Science Teachers & 300 & 8.84 & 1.44 & 598 & 1.74 & 1.96 & NS \\
& 300 & & & & & & \\
Other Teachers & & 9.04 & 1.39 & & & & \\
\hline
\end{tabular}

NS = Not Significant at $\mathrm{P}<.05$.

Table 2: Chi-square $\left(\mathrm{x}^{2}\right)$ analysis of the qualifications of the science teachers in technical colleges and secondary schools

\begin{tabular}{|c|c|c|c|c|c|c|c|}
\hline Qualifications & $\begin{array}{l}\text { Technical } \\
\text { Colleges }\end{array}$ & $\begin{array}{l}\text { Secondary } \\
\text { Schools }\end{array}$ & $\begin{array}{l}\text { Row } \\
\text { Total }\end{array}$ & $\mathrm{DF}$ & $\begin{array}{l}\text { Calculated } \\
\mathrm{X}^{2} \text {-value }\end{array}$ & $\begin{array}{c}\text { Critical } X^{2} \text { - } \\
\text { value }\end{array}$ & $\begin{array}{c}\text { Decision at } \\
\mathrm{P}<.05\end{array}$ \\
\hline NCE & $27(42.5)$ & $58(42.5)$ & 85 & 2 & 16.1 & 5.99 & * \\
\hline HND/B.Sc. & $54(49)$ & $44(49)$ & 98 & & & & \\
\hline $\begin{array}{l}\text { HND/B.Sc. } \\
\text { with } \\
\text { PGDE/B.Sc. Ed }\end{array}$ & $69(58.5)$ & $48(58.5)$ & 117 & & & & \\
\hline Column Total & 150 & 150 & 300 & & & & \\
\hline
\end{tabular}

Where:

NCE $=$ Nigeria Certificate in Education

HND = Higher National Diploma

B.Sc. = Bachelor of Science

B.Sc. Ed = Bachelor of Science in Education

PGDE $=$ Post Graduate Diploma in Education 
Table 3:Chi-Square $\left(\mathrm{X}^{2}\right)$ analysis of the number of science equipment available in technical colleges and secondary schools

\begin{tabular}{|c|c|c|c|c|c|c|c|}
\hline Availabiliy & $\begin{array}{l}\text { Technical } \\
\text { Colleges }\end{array}$ & $\begin{array}{l}\text { Secondary } \\
\text { Schools }\end{array}$ & $\begin{array}{l}\text { Row } \\
\text { Total }\end{array}$ & DF & $\begin{array}{l}\text { Calculate } \\
\mathrm{d} \mathrm{X}^{2}- \\
\text { value }\end{array}$ & $\begin{array}{l}\text { Critical } \\
\mathrm{X}^{2}- \\
\text { value } \\
\end{array}$ & $\begin{array}{l}\text { Decision } \\
\text { at } \\
\mathrm{P}<.05\end{array}$ \\
\hline Available & $68(65)$ & $62(65)$ & 130 & 1 & 90 & 3.84 & $\mathrm{NS}$ \\
\hline $\begin{array}{l}\text { Not } \\
\text { Available }\end{array}$ & $26(29)$ & $32(29)$ & 58 & & & & \\
\hline $\begin{array}{l}\text { Column } \\
\text { Total }\end{array}$ & 94 & 94 & 188 & & & & \\
\hline
\end{tabular}

NS = Not Significant at $\mathrm{P}<.05$ 